\title{
The Age of Appreciation: Reading and Teaching Classic Literature in Australia in the Early Twentieth Century
}

$\mathrm{T}$

HE word 'appreciation' has probably now lost the power it once had to denote sensitive, sympathetic and detailed reflection and commentary on a piece of literature. Its currency as 'liking' or 'gratitude', whether in the vulgar-genteel register of a Kath Day-Knight, or the formulaic courtesies of a modern office environment, has dulled its analytical edge and weakened its evaluative authority to the point where it is difficult to think of 'appreciating' a writer's work as an intellectually serious operation at all. And this despite the fact that the term still retains much of its older, more rigorous meaning when applied to the visual arts, and to certain areas of the general culture - winetasting, for example - where both pleasure and discrimination are highly valued. Why that particular gap has opened up between literature and the fine arts over the last forty or fifty years is a nice question. What is fairly clear, though, is that the terms used to describe more reflective and analytical dealings with literature - terms like 'criticism' and 'interpretation' - are not now, and perhaps never were, perfectly interchangeable with 'appreciation'. And for that reason a closer acquaintance with the term's provenance and meaning is likely to contribute to our understanding of past reading paradigms and practices, especially as regards the reading and study of literature.

Ralph Spaulding's recent work on the teaching of poetry in Tasmania in the first half of the twentieth century usefully highlights the currency of the term 'appreciation' in the discourse of primary and secondary school English education at that time. Its emergence reflects the gradual trend away from a philological to an aesthetic emphasis in the teaching of literature, a trend that was associated with the vaguely defined 'New Education' movement in Britain and the colonies in the late nineteenth century (175-79). ' One striking feature of 'appreciation' as it was invoked in the school contexts he deals with is its stubborn resistance to precise definition or easy application. Many Tasmanian teachers' understanding of the concept, he argues, was limited (180), and furthermore 'few [inspectors] suggested specific strategies to enhance apprecia-

1 As well as Spaulding, see Shayer $(1-25)$. A rough measure of the novelty of the term 'appreciation' in educational discourse in the late nineteenth century might be the fact that it does not occur in the title of any of the 2,000 plus British and American textbooks listed in lan Michael's monumental The Teaching of English from the Sixteenth Century to 1870 (387620). This is not to assert either that the term, in its aesthetic sense, was not current in the general culture prior to 1870 - the $O E D$ suggests that it was - or that earlier instances of 'appreciative' pedagogy cannot be found: D'Arcy Thompson's memoir, for example, first published in Edinburgh in 1864, describes a richly appreciative approach to teaching Greek at the Edinburgh Academy school for boys (63-95). 
tion in the classroom' (184). But by 1920, there were in fact several textbooks available in Australia that did contain excerpts, commentary, activities and exercises explicitly designed to foster literary appreciation, and some of these were recommended for use. Precisely how much actual classroom use was made of such resources, in Tasmania or other states, would be difficult to establish with certainty (let alone how effective they may have been), but it seems reasonable to suppose that where such a book was explicitly recommended by an examining authority - as, for example, Pritchard's Training in Literary Appreciation was in Tasmania (187) - the uptake across the system would have been significant.

Some of the difficulties teachers experienced in understanding and applying appreciation in the classroom may also have had to do with its conceptual ambiguity. 'Appreciation' has a complicated history in the nineteenth century, made more so by its shifting relationship to an older and even more complex concept, that of 'taste'. Reduced to its essentials, by the end of the century, 'appreciation' - which was sometimes equated with 'taste' and sometimes opposed to it - had come to mean an ability to enjoy good literature; and it had begun to circulate widely as one of the chief goals of a literary education, both within the school system but, even more emphatically at this time, within the 'self-improving' culture of worker education and university extension. ${ }^{2}$

Because of its entanglement with 'taste', the presence or absence of the word appreciation is not an infallible guide to meaning. Even well into the twentieth century, a reading adviser like Arnold Bennett, in Literary Taste (1909), could use 'taste' more or less interchangeably with 'appreciation,' in the sense of enjoyment rather than judgement: as a taste for literature rather than taste in literature (13-21). Conversely, Walter Pater had used 'appreciation', in Appreciations (1889), to mean something closer to 'taste' in its other main literary sense: as the ability to make correct judgements about literature. Nonetheless, an ability to understand and enjoy literature, especially less immediately accessible older works of largely undisputed merit - literary classics - seems to have been well established as a desirable outcome of the study of literature by the first decade of the century.

A second striking feature of Spaulding's account of the Tasmanian situation is his demonstration of the space it afforded for vigorous disagreement on method within a broadly appreciative approach. A.B. Taylor, Professor of English at the University of Tasmania from 1926 to 1956, advocated 'rigorous', 'careful', and 'precise' attentiveness to language and literary form as against the rhapsodic rambling - 'a sort of emotional gush', Taylor called it (Spaulding 186) - to which the more 'creative' versions of appreciative pedagogy could descend. But this critique, trenchant as it was, did not signify a return to philology, nor to any other 'extrinsic' form of criticism, so much as a determination to preserve and enrich the quality of the aesthetic experience that a properly appreciative reading

2 See for example George Birkbeck Hill, Writers and Readers (London: Fisher Unwin, 1892), Lectures V-VI; Tucker, Things Worth Thinking About (248-87); Hudson, An Introduction to the Study of Literature (125-27). 
sought to realise. What can seem like a conflict between fundamentally opposed approaches to the study of literature might better be seen as an attempt by a university figure (Taylor) to rescue the appreciative tradition from its own entropic tendencies. Ironically, it may have been that very vagueness that allowed the tradition to accommodate the rigour and precision demanded by academic critics in Britain and America in the 1930s, and to use that rigour and precision to renew itself without abandoning devotion to the enhancement of literary enjoyment as its principal goal and rationale.

What becomes increasingly apparent and worrying in speaking about a tradition of literary appreciation in the early twentieth century is the artificiality of isolating it within one or another sector of the whole 'institution of literature'. Literary appreciation was being taught, valued and practised in primary and secondary schools, in universities (intra- and extra-mural), and in the general reading culture, in several different parts of the world (including Australia), at more or less the same time. And the boundaries between the various cultural, national and educational sectors were relatively porous: lines of cultural influence, commercial exchange and administrative responsibility passed from one to the other in several different directions.

A way of capturing a sense of the international and cross-institutional character of literary appreciation is to consider some of the teachers, critics, academics and publishers - British, American and Australian - whose books helped to disseminate the idea and the practice of appreciation, directly or indirectly, across the Australian education system and Australian book culture during the first half of the twentieth century. The clearest and most consistent exponent of literary appreciation, and one of the most persuasive and engaging advocates for its central role in the teaching of literature, was Richard Green Moulton. ${ }^{3}$ Born in Preston in 1849, Moulton was a prominent lecturer in University Extension almost from its inception in the early 1870 s. He later emigrated to the United States, played a key role in organising the American University Extension program, and in 1892 was appointed the first Head of the new School of General Literature at the University of Chicago.

Moulton published about a dozen substantial critical monographs: on Shakespeare, ancient Greek drama, the Bible, 'World Literature', the novel, and the theory and practice of interpretation. For all its apparent diversity, however, most of his work rests upon a single, very firm distinction which he insisted upon from his first published book to his last, that between 'inductive criticism' and 'judicial criticism'. By judicial criticism, Moulton means the kind of commentary on works of art and literature that seeks to judge their merits, whether comparatively, impressionistically, or with reference to fixed standards. By inductive criticism he means, simply, interpretation, that is, the systematic investigation of the structure and meaning of literary works. In its earliest and simplest formulation, in his book Shakespeare as a Dramatic Artist (1885), he expresses it as follows:

3 Biographical details about Moulton are from S[hailer] M[attews], 'Moulton, Richard Green', Dictionany of American Biography, vol. XIIl pp. 291-92. 
Judicial criticism ... analyses literary works for grounds of preference or evidence on which to found judgments; inductive criticism analyses them to get a closer acquaintance with their phenomena. (2)

As Moulton saw it, the history of criticism thus far had been largely a history of judicial criticism. It had also, however, been a history of the triumph of authors over critics, as the great writers asserted their authority, slowly but inexorably, over the misguided fault-finding and rule-mongering of their critical contemporaries, in a steady evolution of taste that Moulton did indeed regard in broadly Darwinian terms. Inductive criticism, on the other hand, like inductive science, was a serious and sustained exploration of Nature - that part of nature called Literature - in both its historical and its formal aspects. In its simpler forms - as in some of his own excellent analyses of dramatic form in Shakespearean plays - such criticism actually promoted appreciation by 'scaffolding' the reader's or spectator's pleasure in every aspect of the play.

Later on in his career, Moulton accepted the practical utility of judicial criticism - in newspapers and magazines, for example - as a means of culling the overwhelming volume of contemporary writing. He had in any case always enthusiastically embraced the work of the great judicial critics of the past Dryden, Johnson, Hazlitt, Lamb, and others - as great literature in its own right. But throughout his career he held firm to the view that judicial criticism, qua criticism, was of no direct value to the study and teaching of classic literature, because it erected what he called 'a barrier to appreciation, [which was] opposed to that delicacy of receptiveness which is a first condition of sensibility to impressions of literature and art' (Shakespeare 6-7).

Moulton's direct influence on the teaching and study of literature in Australia might have been fairly limited: he certainly never visited Australia, and there is a scattering of his books, no more, in university libraries and secondhand bookshops around the country. ${ }^{4}$ His indirect influence, however, and especially his insistence on the primacy of positive appreciation over negative judgement in the teaching of literature, was greater than this might suggest, especially between the wars. One important conduit - disproportionately influential perhaps, at least in schools in New South Wales because of his role as a lecturer at the Sydney Teachers College - was George Mackaness, whose book Inspirational Teaching (1928) was based on a series of College lectures describing his own earlier experiments in English teaching while at Sydney's Fort Street Boys' High (vii). Because the book is not formally referenced it is difficult to quantify Moulton's influence - Mackaness's main acknowledged debt is to H. Caldwell Cook's The Play-Way (1917) (viii) - but 'Dr Moulton' is mentioned by name (and with an assumption of its familiarity to his readers) in connection with the structural analysis of Shakespearean plays (68). His chapters on the teaching of novels and the English essay also show signs of Moulton's influence (though his name is

4 The statement is based on Web searches of university library catalogues and online secondhand bookshop inventories in Australia. The Libraries Australia database displays 105 Moulton titles currently held in Australian libraries, most of them single volumes of his multivolume edition of the Bible for Modern Readers. 
not mentioned in these connections); and in a discussion of strategies for teaching the Bible as literature - Moulton's central life-project - Mackaness talks about Quiller-Couch's three lectures 'On Reading the Bible' from On the Art of Reading (1920), in which the latter makes intensive and deferential use of Moulton's Modern Reader's Bible (21 vols., 1896-98) (Quiller-Couch, 154-78). Appreciation, it would seem, had by now become a thoroughly transatlantic ideal.

There were also three non-Australian authors of textbooks used in Australian schools in the interwar period who were great admirers of Moulton's work, and who referred to it repeatedly, and cited his books - especially the ones on 'World Literature', critical theory, and Shakespeare - in lists of recommended reading for students. The oldest, and probably the most important of these authors in the Australian context, was William Henry Hudson (1862-1918), not to be confused, if at all possible (most libraries do not find it possible, however) with his older and more famous namesake, the Anglo-American-Argentinian naturalist and writer (1841-1922), author of Green Mansions, The Purple Land, A Hind in Richmond Park, and much else. The lesser-known W.H. Hudson though very familiar to generations of Australian schoolchildren and adult learners - was a Londoner by birth. He grew up in Bristol, spent a year in New York, then returned to England and worked for some years as Herbert Spencer's private secretary. In 1893 he moved to California where for nine years he was a Professor of English at Stanford University before moving back to Britain early in the new century to take up a lecturing post with London University Extension, as the immediate successor to the redoubtable John Churton Collins. Apart from a brief stint at the University of Chicago (presumably in Moulton's School of General Literature), he continued in that position until his early death from heart disease, aged 56 , in $1918 .^{5}$

In the last twenty years of his life, Hudson - who appears never to have taken a degree of any kind - wrote some forty books, including studies of Herbert Spencer (his erstwhile employer), John Smith, Rousseau, Napoleon, Sir Walter Scott, the French Third Republic, the Renaissance, and a veritable swag of books on English and French history and literary history. He wrote individual studies of at least ten British, American, French, and German poets in a Harrap series called 'Poetry and Life', of which he was the General Editor, and which comprised more than thirty 150-page critical 'appreciations'. Many of the 'Poetry and Life' books were acquired, and lent out, by University Extension Board libraries around Australia well into the 1940s. Two of his larger books, $A n$ Introduction to the Study of Literature (1910) and An Outline History of English Literature (1913), were reprinted at least twenty times up to the 1960 s, and were

5 A.A. Jack, 'William Henry Hudson: A Memoir', in W.H. Hudson, A Short History of French Literature (London: G. Bell and Sons, 1919) v-xiv. 
certainly used as textbooks in some Australian state and private secondary schools. ${ }^{6}$

The other two authors of textbooks used in Australian schools both had Australian connections. Francis Henry Pritchard (1884-c.1950), author of $A$ Training in Literary Appreciation (1922) and a dozen other graded textbooks on literary appreciation and composition, was Senior English Master at Devonport High School in Tasmania from about 1915 to 1924, after which he returned to Britain (Harrap, Some Memories 67). Some years later he wrote Books and Readers (1931), a book of reading advice for a general audience - at 250 pages one of the longest in that genre, and certainly one of the most engagingly written. He also edited many books of recent and classic essays and short stories, which, on the evidence of the large number of second-hand copies in online Australian bookshop inventories, sold well in Australia during the 1920s and 1930s. As a former teacher, Pritchard was an active participant in the British education debates leading up to and following the Newbolt Report of 1921 (Harrap Mercury 1931-32), and his recommended readings include key figures on the side of progressive reform in English literary education such as Sir Philip Hartog, Hardress O'Grady, George Sampson, Edward Greening-Lamborn, W.S. Tomkinson and Sir Arthur Quiller-Couch. He also makes reference to Hudson and, of course, Moulton, nearly all of whose books he recommends in different chapters of Books and Readers.?

The third member of the trio was Henry Arthur Kellow (1881-1935), graduate of Glasgow University, headmaster of Rockhampton Grammar School from 1912 until his death, and well-known to students of Queensland literature for his groundbreaking book The Queensland Poets (1930). In the present context, though, his two other books were more important: A Practical Training in English (1911) and Burns and His Poetry (1918), the latter being one of the slimmer volumes in Harrap's 'Poetry and Life' series. Practical Training, in particular, which Kellow completed shortly before moving to Rockhampton from Allan Glen's School, Glasgow, was widely adopted as an intermediate textbook in the Scottish secondary school system, and (after Kellow's arrival in Rockhampton) in a number of Queensland schools as well. It was reprinted

6 No strictly quantitative claims are being made in this essay about the extent of distribution or uptake of these authors through the Australian school system. The evidence of bookplates, inscriptions, and dated revisions and reprintings in several dozen sighted copies, together with that of Harrap sales catalogues and company magazines in the British Library (Harrap Catalogues, Harrap Mercury, Harrap Book News, Harrap Review), and of the memoirs and business correspondence of three generations of Harraps (University of Reading Publishing History Archive), supports the claims of ready availability in Australia and of purchase by some secondary schools and Extension libraries in several states.

7 References and recommendations saturate Pritchard's monographs, for example in $A$ Training in Literary Appreciation, to Moulton (37, 68, 149, 190-92), Hudson (68, 131, 167, 190-2); in Books and Readers, to Moulton, Hudson, Hartog and Greening-Lamborn (245-48). His account of his participation in debates on the teaching of English before and after the Newbolt Report is outlined in a series of articles for the Harrap Mercury, 1931-32, and earlier, more briefly, in 1928. 
twice before 1922, then revised and enlarged in that year, and reprinted again in 1924 (McDonald 26-27).

These three authors - Hudson, Pritchard and Kellow - share a number of characteristics, in addition to their ready availability and use in Australian secondary schools and University Extension courses and libraries. One is their admiration for Moulton. Hudson, in particular, quotes large slabs of him in his Introduction to the Study of Literature - on 'inductive criticism', and on ancient Greek drama - explaining and commenting on them at length (176-77, 269-71, 278-80), though he was not altogether uncritical, taking issue with Moulton's belief in the possibility of a 'scientific criticism' (278). A second common factor is that all three were published by Harrap - in the case of Kellow and Pritchard, exclusively. This was not a coincidence: all three were personally recruited as authors by the founder of the firm, George G. Harrap, and all subsequently became his personal friends. In 1924, on a visit to Australia and New Zealand (during which he stayed with Kellow in Rockhampton), Harrap persuaded Pritchard to leave his teaching job in Tasmania and return to England to become the firm's education editor, a position he held for the next 35 years. Even Moulton, though he never published with Harrap during his lifetime, had two of his books reissued posthumously by Harrap in the late 1920s. The firm of Harrap, founded in 1901, in fact appears to have developed a remarkably comprehensive and coherent educational and general list in the first thirty years or so of their existence, the overarching rationale of which was, precisely, the spread of cultural appreciation to school and general populations throughout the Empire and even, by way of partnerships with other firms, in the United States as well (Harrap, Some Memories 12-19).

Harrap was certainly not the only British publisher with an interest in increasing Australians' cultural capital in the early years of the twentieth century: Oxford, Macmillan, Allen \& Unwin, Dent and Heinemann, for example, were all engaged in roughly parallel enterprises, and the first two were bigger, and all five were older firms than Harrap. But Harrap does seem to have established a larger footprint during this period than their core business of foreign-language dictionaries and textbooks would lead one to expect. And if the dissemination of 'appreciative capability'- not just in literature, but in art, music, history and philosophy - was the central project driving the firm's expansion in these years, then Hudson and Pritchard in particular were key contributors. Others included the history editor, also a prolific Harrap author in her own right, Dorothy Margaret Stuart, the literature and drama historian J.W. Marriott, and the pioneering historian of reading, Amy Cruse.

The point of stressing the Harrap connection is to suggest that the combined influence of Hudson, Pritchard and Kellow in Australia was probably even greater than the sum of their individual book-adoptions and sales. This is because they were part of a large, vigorous, and highly co-ordinated project certainly imperial in scope, and with American and French offshoots as well ${ }^{8}-$

8 The American connection operated through Harrap's close reciprocal arrangements with the publishers D.C. Heath, Thomas Crowell, and Houghton-Mifflin. The French connection rested 
and the project involved many authors (some of them on the staff, others closely networked through the firm) and many carefully targeted series - 'The Harrap Library', 'Poetry and Life', 'The Simple Guide Series', 'Readers of Today', 'Told Through the Ages', 'The Romance of Knowledge', to name some of the best-known.

As far as literature was concerned, Harrap's corporate aim was to increase people's capacity to enjoy classic literature by teaching, or training, or encouraging them to read better, that is to say more carefully, attentively, sensitively and knowledgeably. Pritchard - with an approving nod to Arnold Bennett's bracing exhortations of twenty years earlier - put it this way for the general audience to whom his Books and Readers was directed:

The reader should magnify his calling. He should reflect that he is as necessary to the world of books as is the writer. It is to small purpose that we have the works of Shakespeare and of Milton if we have no readers who are able to appreciate them. An old and very sound principle has it that "Great things are only maintained by the same means whereby they were created." The purpose of this book is to incite the reader to equip himself for the full enjoyment of the best that literature has to offer and so to prolong the impulse which brought it into being. (Pritchard, Books and Readers 8)

Seven years earlier, in a 1924 Preface to his most widely adopted book for schools, Training in Literary Appreciation (originally published 1922), the tone is more focussed and polemical. This reflects Pritchard's strong support for the analysis and recommendations of the Newbolt Report (1921), which placed English at the centre of a humane, liberal and broad education system, and stressed the importance of students' imaginative and emotional experience of reading, and of learning to appreciate the aesthetic and creative dimensions of literature (Shayer 67-74).

The average reader sadly needs guidance, and the failure of some of the older methods does not justify the assumption that it is impossible to meet this need. It is, indeed, a most dangerous heresy which says that there is nothing to be done for the reader but to impart to him a knowledge of the rudiments, and then leave him to work out his own salvation as best he may. The result of that policy is seen today, when we have a very few readers of discrimination, and a great majority to whom 'book' and 'novel' are synonymous terms. We are all readers now, if by that is meant the ability to go from title-page to colophon with a certain amount of comprehension of the matters of fact contained by the print. But if the ability to weigh, to judge, and to appreciate is meant, then comparatively few of us dare lay claim to the title. ... The idea [of the present book] is not to put the reader out of conceit with a swift and thrilling narrative, but to show him how much more there is if he will but cultivate the seeing eye and the hearing ear. In short, the aim is to broaden the basis of enjoyment. The reader will certainly not be less susceptible to the excitement of rapid movement because he has learnt to appreciate those subtler beauties of which the best literature is full. (Pritchard, Training 6) wrote several books on French history and literature. 
It should be noted, however, that the 'dangerous heresy' he rejects in the second sentence, and the attachment to 'swift and thrilling narrative' which he clearly regards as somewhat inimical to literary appreciation, are both typical rather of the anti-analytical and anti-canonical slant of some of the ultra-progressive postNewbolt method books of the early 1920s than of the utilitarianism and vocationalism criticised by the Newbolt Report itself. ${ }^{9}$ Pritchard, in other words, was defining his position on English method with precise reference to preNewbolt conservatives, on the one hand, who used literary texts to teach English grammar and vocabulary, and post-Newbolt radicals on the other, who wanted children to read what and how they chose. For Pritchard, as for Hudson, Kellow and Moulton before him, teaching English chiefly entailed finding ways of enabling the student to enjoy - not just to have read, or to know about - the best literature the world had to offer.

Within this group there were differences of emphasis: Kellow's Practical Training retains more of a pre-Newbolt tendency to make the chosen texts do double duty as literature, and as exemplary material for the grammar and history of the language. Hudson and Moulton are both more likely to engage in detailed structural analysis, generic description and historical contextualisation of texts than Pritchard, who revels in the verbal nuances, rhythmic subtleties and tonal complexities of literary language. What they all share is a conviction that 'appreciation' should be the principal object of English teaching method, and that appreciation means the ability to enjoy, take pleasure in, the great works of literature.

The frequently stated importance of pleasure in the student's encounter with literature is a notable feature of the 'appreciative' tradition of English-teaching, reflecting perhaps a general early twentieth-century reaction against Victorian traditions of moral and social self-improvement, but also the institutional provenance of positive appreciation in Victorian extramural education - the working men's college and university extension (Maurice, Willmott, Shaylor). Literary pleasure was not, of course, equated with the vulgar or sensual pleasure associated with popular entertainment and pulp fiction; but on the other hand absolute distinctions between literary pleasure and other forms of pleasure seem not to have been insisted upon (though this did begin to occur somewhat later, in the 1930s). After all, if reading the classics were to be seen as an alternative to other, less worthy pleasurable activities in the lives of ordinary people - as commercial purveyors of the classics assuredly hoped they would - then it was probably wise not to insist on the complete dissimilarity of the two kinds of pleasure.

For Hudson and Pritchard - as for Arnold Bennett - the pleasures of 'good reading' were indeed sensuous, if not sensual, at least in part; hence their tireless efforts to 'sensitise' inexperienced readers to the pictorial richness, arresting and

9 An example would be Robert Finch, The Approach to English Literature (1923), who wanted more poetry but less teaching and analysis of it, and who believed that pulp fiction should be read as a prelude to 'real literature' (Shayer 98). 
beautiful sounds, and voluptuous feel of great writing (particularly when read aloud), as also to the local subtleties and surprises to be found and experienced in words and rhythms. ${ }^{10}$ But the pleasures of literature were above all emotional pleasures (T.S. Eliot's distinction between 'emotions' and 'feelings' in literature [17-21] seems not to have been widely understood or accepted in these circles). These were generated, to a limited extent, by the affective, quasi-musical properties of form, but to a much greater extent by the emotions expressed by the author in the work, either directly or indirectly through characters, and by the sympathy they engender in the reader. As Hudson put it:

We want first of all to become, not scholars, but good readers; and we can become good readers only when we make our reading a matter of close and sympathetic companionship. ... A great book owes its greatness in the first instance to the greatness of the personality which gave it life. (Introduction 15)

Or again,

Our study of literature thus begins in a very simple and humble way. We take a great book, and we try to penetrate as deeply as we can into its personal life. We make our reading of it, to the fullest extent possible to us, a matter of actual intercourse between its author and ourselves. (Introduction 17)

Hudson is not quite the biographical reductionist he may seem: his notion of 'the author' is probably closer to Wayne Booth's 'implied author' than to the biographical individual, though he avoids making any such sharp distinction. He is quite wary of literary biographies as a resource, acknowledging that 'In our study of the personal life of literature we shall of course be greatly helped by the judicious use of good biography', but only in the way, and to the extent, necessary to 'cultivate a spirit of sympathy - at least of provisional sympathy with our author' (Introduction 22, 25).

In similar fashion, his warm advocacy - and his own practice - of 'the historical and sociological method' of literary study is always rigorously subordinated to the need to establish a bond of sympathy with the 'personality' behind the work, and the emotional gratifications that derive from it. The following is, I think, one of the more cogent early twentieth-century statements of the value of literary scholarship, one not entirely without contemporary resonances:

Henceforth we need not find any period of literary history wholly wanting in the quality of life. Much of the literature of the past must on our first approach to it necessarily seem to us both dull and unattractive - matter for the specialist, not for the general student. Thoughts, feelings, ideals change; the fashion of their utterance changes likewise; chasms yawn between us and bygone generations; and many a book which once held its readers spellbound seems a vapid and futile thing to us who belong to another age, and are touched by other modes of passion and other

10 See especially Pritchard, Training, which has separate chapters on the delights in 'Unity and Contrast', 'Rhythm', 'The Figures of Speech', 'Words and Letters', 'The Forms of Verse', 'Story and Setting', 'Personality and Style', and 'The Sublime'. Reading aloud is considered indispensable, not only by Pritchard, but by Hudson (Introduction 125-27), Tomkinson (5178 ), and many others. 
manners of speech. Our textbook writers and professional critics seldom acknowledge this, and by their failure to do so they often discourage young and untried students, who are apt to feel that their own inability to take a vital and personal interest in many books which figure prominently in the annals of literature is entirely due to some radical defect in themselves. This is not necessarily so. Of even the greater books of the past there are comparatively few which have not suffered more or less seriously, while all but the very greatest have suffered much, from the changes which are ever going on in life, fashion, taste; and it is at once idle and unwise to attempt to deny this fact or to shirk its obvious implications. But it is precisely here that the value of what we call historic or sociological study of literature should become apparent. When we take up the historic point of view, we can carry every book, even the dullest, back into the life out of which it originally grew; we can place ourselves to some extent in the relations of its first readers with it; and the result is that the rich life-blood of humanity begins to flow once more through its long-dead pages. Forms of art, which to us are simply archaic - subjects and methods which can never now be revived - suddenly become of interest. (Introduction 42-43)

'Good reading,' he concludes, 'is better than all scholarship, and the cultivation of the art of good reading infinitely more important than all the acquisitions of scholastic learning. The study of literature in all its phases and details may be so planned and conducted as to render our enjoyment of literature ampler and richer. If it does this, its justification is incontestable. If it fails to do this, then, whatever else it accomplishes, it misses its true purpose' (Introduction 62).

Appreciative reading, simply put, was about maximising aesthetic pleasure. It was about training oneself to enjoy the manifold beauties of form and style to be found in the great works of the past, about cultivating a sympathetic bond with the author, and responding to the work with emotional depth and honesty. Its advocates in the British university system were therefore highly critical of anything that erected obstacles to those aims - philology, for example: witness John Churton Collins's attacks on the philological clutter of the Clarendon Press editions of classic English authors (Collins 57-60). As a reading strategy, appreciation tended to be positive rather than negative, interpretative rather than evaluative, 'intrinsic' rather than 'extrinsic' in its focus. By and large, an appreciative reading of a text was unlikely to be a political, moral, or allegorical reading of the work as a whole, though a fully appreciative reader would be capable of identifying, and enjoying, such elements within the work itself.

The Harrap books themselves are no more than the tip of the Appreciation Iceberg. They elaborated the idea of appreciation more fully and programmatically than most, which is why they present a useful case study; but, as was earlier observed, there were several other publishers at this time, mainly British, but a few American as well, who were supplying Australian markets with English textbooks and reading-advice books that also promoted appreciation of the classics, if somewhat less consistently and self-consciously than Harrap. Furthermore, there was a powerful over-determination operating in favour of an appreciative regime of reading in Australia, namely the post-colonial factor. Put simply, if Australians could enjoy (or be trained to enjoy) the likes of Shakespeare, Milton, Scott, and the King James Bible, that constituted a kind of 
'proof' of their essential English-ness, of the fact that the crimson thread of kinship was still there. That was, in a sense, the ideological project of an anthology like J.J. Stable's The Bond of Poetry (1924), one of the most popular high school texts of the interwar period, which combined English and Australian poems in order to 'keep nationalistic Australians linked to their British heritage' (Wilde 30). But it is easy to 'over-politicise' this intention, to see it as an effort to preserve the unity of the Empire rather than, as Stable himself describes it in the Preface, as an attempt to preserve the affective and aesthetic access of Australian students to the English poetic canon - access which, in Stable's view, was jeopardised by the 'widening gulf' between English and Australian life experiences. His anthology was designed to give teachers the opportunity to develop students' appreciation for poetry by exposing them, first of all, to examples of narrative, descriptive and patriotic poetry which related to the local environments, history and folklore with which, as Australians, they were directly familiar, and only then transferring that appreciative capacity to earlier British poems in the same three genres.

In Australia, and in other British Dominions, where a distinct national development is now evident, contemporary local poetry should be studied, especially in the junior forms of the Secondary Schools, if the greater poetry of the past is to be properly appreciated and understood. (Stable vii)

Whether the two-stage technique ever actually 'worked' or not, it is at least clear that Stable's primary aim was to have the anthology used as an instrument for producing a particular kind of reading outcome - the ability to appreciate older poetry in English - rather than an ideological belief about, or attitude towards, Australia's place in the British Empire. Given what we know about Stable's politics, the temptation to politicise his literary activities is always present. Professor of English at the University of Queensland, he was also Chief Military Censor for Queensland in the First World War, and played an important and distasteful role in Brisbane's 'Red Flag' riots of March 1919 (Evans 22). To do so, however, is to fail to recognise the relative autonomy of his interests in literature and literary education, and to obscure their wider national and international connections.

Like Stable, most of the other occupants of humanities chairs in Australian universities up to the Second World War were enthusiastic advocates and practitioners of literary appreciation, and believed that local writing could be used to 'kick-start' a responsiveness to less accessible and familiar works in English (or English translation). T.G. Tucker, Professor of Classics at Melbourne University from 1885 until 1920, also had a philosophical interest in the ideas of appreciation and judgement. In connection with this, he published several essays and a monograph investigating topics such as aesthetic pleasure, emotional truth, and 'interestingness' in literature, arguing their priority over moral teaching, and illustrating them with examples from Classical, Renaissance and Romantic literature (see Tucker and note 2). Mungo MacCallum in Sydney, George Cowling in Melbourne, and J.I.M. Stewart in Adelaide all shared with Tucker (and with Moulton, Hudson, and Pritchard) the view that aesthetic 
pleasure was the necessary starting-point for understanding great art and literature and making it one's own, and that appreciation was the means by which that pleasure could be realised."

Such reinforcement 'from above' of appreciative reading in the schools and general community carried considerable weight in the first half of last century, both because the universities in effect dictated the secondary school curricula, and because all of these professors, their eminence notwithstanding, greatly widened their sphere of public influence by writing 'literary leaders' and columns in the newspapers and by presenting literary appreciations of classic writers as lectures - often later published as pamphlets - to bodies such as university extension, the New Education Fellowship, and the Workers' Educational Association - somewhat to the irritation of education reformers like Peter Board and G.V. Portus, who thought adult education lectures should be about the state of the modern world rather than 'belles lettres' (Whitelock 16971). ${ }^{12}$

It has become customary, especially in the wake of Leigh Dale's important book, to cast the anglocentric 'God-professors' of Australian humanities departments in the first half of the century in a mainly negative light, and from the standpoint of Australian writing this is hardly unfair. Most of them were opposed to teaching Australian literature separately from the historical canon of English literature, and this, together with the contempt some of them (most notoriously Cowling and Stewart) occasionally expressed for the local literary product, undoubtedly drove a wedge between writers and the universities for decades, and may well have helped to foster something of a Cringe (both 'Direct' and 'Inverted') about Australian writing among the reading public, particularly between the wars. All these points having been granted, though, it is also possible to see their attitudes and activities in a more positive light, as expressing their determination to maintain pleasurable access for Australian readers, across increasingly formidable barriers of time and distance, to the highest peaks of literary accomplishment in the English language. Their adherence to an appreciative approach to the study of literature, one that sought above all to facilitate, refine and maximise the pleasure of reading those classic texts, was the strategy by which they - together with their fellow enthusiasts in secondary schools and adult education - hoped to keep the conduit to the classics in good repair.

What was at stake for these men was the quality of aesthetic pleasure available to Australian readers. There was nothing inherently elitist about their project: its progressive premise was that appreciation was a broadly educable

11 This paragraph over-rides significant differences among these various scholars in order to highlight a common affiliation to 'appreciation'. On some of these differences, and on the politics of their appointments, see Dale (47-104). Cowling and Stewart, for example, were both more interested in the emotional aspect of literary reading than their predecessors, Tucker and MacCallum.

12 Leigh Dale quotes contemporaneous comments on Tucker's widespread influence in Melbourne, through his teaching, public lectures and weekly Argus essays, from the beginning of the 1890 s (33). 
capacity, not socially determined or differentiated (except insofar as education itself was less than universal). Nor was it an inherently anglophile project, except insofar as it accepted, as most people did, the 'verdict of history' as to the superiority of certain older, mainly British authors and works over anything very recently written in English, whether in Australia, North America, or Britain itself. Perhaps understandably, some of them felt that one of the main threats to their approach was the kind of literary nationalism that tended to over-praise inferior work, thereby lowering the standard or, more precisely, degrading the quality of the highest aesthetic pleasure available.

In fact, there was, and is, no necessary conflict between a commitment to building a national literature, and a commitment to teaching people to appreciate the classics of English and world literature. The career of George Mackaness (1882-1968), editor, anthologist, historian, biographer and bibliophile may serve as a concluding case in point. His lifelong devotion to the cause of Australian literature seems never to have lessened his enthusiasm for teaching Australian trainee teachers how best to appreciate, and to enable their own students to appreciate, the aesthetic qualities of classic English literature. ${ }^{13}$ The balanced commitment that Mackaness, and in a somewhat different way his occasional collaborator Walter Murdoch, achieved in the early years of last century might be taken as a distant signpost to how literature might (just possibly) be nurtured, taught and read in Australia in the twenty-first century.

\section{WORKS CITED}

Alter, Robert. The Pleasures of Reading: In an Ideological Age. New York: Simon \& Schuster, 1989.

Bennett, Arnold. Literary Taste: How to Form It, with Detailed Instructions for Collecting a Complete Library of English Literature (1909). Edited with additional Lists by Frank Swinnerton. Harmondsworth: Penguin, 1938.

Buckridge, Patrick. "'How to Read Books": Reading-Advice Books in Britain and North America, 1870-1960.' Bibliographical Society of Australia and New Zealand Bulletin 26.2 (2002): 67-80.

Collins, John Churton. The Study of English Literature: A Plea for Its Recognition and Reorganization at the Universities. London and New York: Macmillan, 1891.

Dale, Leigh. The English Men: Professing Literature in Australian Universities. Toowoomba: Association for the Study of Australian Literature, 1997.

Dictionary of American Biography, 10 vols. New York: Scribners, 1928-36.

Eliot, T.S. 'Tradition and the Individual Talent.' 1919. In Selected Essays. London: Faber \& Faber, 1963. 13-22.

Evans, Raymond. The Red Flag Riots: A Study of Intolerance. St Lucia: University of Queensland Press, 1988.

Harrap, George G. Some Memories, 1901-1935: A Publisher's Contribution to the History of Publishing. London: Harrap, 1935.

Harrap, George G. \& Co. Catalogues of Current and Advance Publications. London: Harrap, 1927 -.

13 See, for example, his chapters on 'Modern Methods of Studying Shakespeare', 'The Study of Literary History and Biography', 'The Study and Teaching of the Novel', and 'The Study and Teaching of the English Essay', in Inspirational Teaching (60-148). 
Harrap Mercury. London: Harrap, 1924-1932.

Harrap Book News. London: Harrap, 1938-1939.

Harrap Review, London: Harrap, 1950- .

Hudson, W.H. An Outline History of English Literature. 1913. London: G. Bell and Sons, 1955.

- An Introduction to the Study of Literature. 1910. George G. Harrap, 1960.

Kellow, H.A. A Practical Training in English. 1911. New and rev. ed. London: George G. Harrap, 1922.

- Burns and His Poetry. Poetry and Life. London: George G. Harrap, 1918.

Kermode, Frank. Pleasure and Change: The Aesthetics of Canon [sic]. The Berkeley Tanner Lectures. Ed. Robert Alter. Oxford and New York: Oxford UP, 2004.

Lyons, Martyn. 'Texts, Books and Readers: Which Kind of Cultural History?' In Books, Readers, Reading. Ed. David Walker, with Julia Horne and Martyn Lyons. Australian Cultural History 11 (1992): 1-15.

Mackaness, George. Inspirational Teaching: A Record of Experimental Work in the Teaching of English. London and Toronto: J.M. Dent, 1928.

Maurice, F.D. The Friendship of Books. London: Macmillan, 1880.

McDonald, Lorna. Henry Arthur Kellow 1881-1935. Foundation for Australian Literary Studies. Townsville: James Cook University, 1981.

Michael, Ian. The Teaching of English: From the Sixteenth Century to 1870. London and New York: Cambridge UP, 1987.

Moulton, R.G. Shakespeare as a Dramatic Artist: A Popular Illustration of the Principles of Scientific Criticism. 1885. $3^{\text {rd }}$ ed., rev. and enlarged. Oxford: Clarendon, 1906.

Pater, Walter. Appreciations: With an Essay on Style. 1889. London: Macmillan, 1927.

Pritchard, F.H. Training in Literary Appreciation: An Introduction to Criticism. 1922. London: George G. Harrap, 1926.

- Books and Readers. Simple Guide Series. London: George G. Harrap, 1931.

Quiller-Couch, Arthur. On the Art of Reading. 1920. London: Cambridge UP, 1924.

Right Reading: Words of Good Counsel on the Choice and Use of Books, Selected from the Writings of Ten Famous Authors. Enhanced facsimile reprint of 1901 ed. Amsterdam: Fredonia, 2004.

Shayer, David. The Teaching of English in Schools 1900-1970. London and Boston: Routledge and Kegan Paul, 1972.

Shaylor, Joseph, comp. The Pleasures of Literature and the Solace of Books. London: Wells, Gardner \& Darton, 1898.

Spaulding, Ralph. 'Poetry's "Formative Power": Teaching Poetry in Tasmania 1900 1950.' Australian Literary Studies 22.2 (Oct. 2005): 175-91.

Stable, J.J., ed. The Bond of Poetry. London: Oxford University Press and Humphrey Milford, 1924.

Thompson, D'Arcy Wentworth. Day Dreams of a Schoolmaster. Heath's Pedagogical Library 33. Boston: D.C. Heath, 1906.

Tomkinson, W.S. The Teaching of English: A New Approach. Oxford: Clarendon, 1921.

Tucker, Thomas G. The Judgment and Appreciation of Literature. Melbourne: Melbourne UP in association with Macmillan, 1926.

Tucker, T.G. Things Worth Thinking About. Melbourne: Lothian, 1909.

Whitelock, Derek. The Great Tradition: A History of Adult Education in Australia. St Lucia, Qld: U of Queensland P, 1974.

Wilde, William, Joy Hooton, and Barry Andrews. The Oxford Companion to Australian Literature. Melbourne: Oxford UP, 1985.

Willmott, Robert Aris. Pleasures of Literature. $5^{\text {th }}$ ed. London: Bell \& Daldy, 1860. 